\title{
APLIKASI PENGENALAN ANATOMI TUBUH MANUSIA BERBASIS ANDROID
}

\author{
Rusli Wanasuria ${ }^{1}$, Fiqih Ismawan ${ }^{2}$, Heriyati ${ }^{3}$ \\ Program Studi Informatika, Fakultas Teknik dan Ilmu Komputer, Universitas Indraprasta PGRI \\ Jalan Raya Tengah No 80, Kelurahan Gedong, Pasar Rebo, Jakarta Timur \\ ruslibruce@gmail.com¹,vQ.unindra@gmail.com², erymatematika@gmail.com ${ }^{3}$
}

\begin{abstract}
Abstrak
Di Zaman sekarang ini perkembangan teknologi informasi terutama di Indonesia semakin bertambah maju. Namun masih kurang tersedianya suatu aplikasi mobile tentang anatomi tubuh manusia. Informasi yang terdapat pada buku - buku pun terbatas, sehingga, tidak dapat dimanfaatkan dengan baik dan membuat kurangnya minat membaca bagi siswa sekolah juga masyarakat umum. Berdasarkan penjelasan tersebut, maka peneliti mengangkat judul "Aplikasi Pengenalan Anatomi Tubuh Manusia Berbasis Android". Berdasarkan identifikasi masalah di atas maka dapat dirumuskan bagaimana pembuatan aplikasi pengenalan anatomi tubuh manusia dengan informasi yang menarik disertai cara kerja fitur yang mudah untuk bisa diperoleh dari aplikasi tersebut. Tujuan penelitian ini adalah membuat sebuah aplikasi pengenalan anatomi tubuh manusia yang lebih menarik dengan menggunakan media smartphone secara digital sehingga mudah di akses kapanpun, dimanapun dan memberikan informasi pembelajaran yang efektif dan efisien secara offline. Selain itu, masyarakat umum dapat merasakan kemudahan dalam mengolah data untuk mengaksesnya. Metode penelitian yang digunakan aplikasi ini adalah metode prototyping, dari hasil penelitian dapat mengasah dan menambah pengetahuan serta wawasan tentang anatomi tubuh manusia yang ada pada tubuh kita.
\end{abstract}

Kata Kunci: Anatomi Tubuh, media smartphone, Android

\begin{abstract}
Nowadays, the development of information technology, especially in Indonesia, is increasing. But there is still less availability of a mobile application about human anatomy. The information contained in the books is limited, so it cannot be utilized properly and makes a lack of interest in reading for school students as well as the general public. Based on the explanation, the researcher raised the title of "Android-based human body anatomy recognition Application". Based on the identification of the above problem, it can be formulated how to create anatomy recognition application of human body with interesting information along with how easy features work to be obtained from the application. The purpose of this research is to make a more attractive human anatomy recognition application using smartphone media so that it is easy to access anytime, anywhere and provides effective learning information and efficiently. In addition, the general public can feel the ease in processing the data to access it. The research methods used by this application are prototyping methods, from the results of the research can hone and increase knowledge and insight on the anatomy of human body that exists in our body.
\end{abstract}

Keywords: Anatomy of the Body, smartphone media, Android

\section{PENDAHULUAN}

Kebutuhan manusia akan teknologi informasi dan komunikasi di masa sekarang ini telah menjadi suatu hal yang wajib, dimana hampir segala aspek kehidupan sehari - hari tidak terlepas dari teknologi informasi dan komunikasi. Perkembangan teknologi informasi dan komunikasi banyak dimanfaatkan manusia untuk menunjang dan memudahkan aktifitas kehidupan sehari - hari.

Jika dilihat pada saat sekarang ini perkembangan teknologi informasi terutama di Indonesia semakin berkembang. Dengan adanya teknologi informasi dan komunikasi dapat memudahkan untuk belajar dan mendapatkan informasi yang dibutuhkan dari mana saja, kapan saja, dan dari siapa saja.

Media aplikasi pembelajaran mempermudah sarana dalam pembelajaran, namun saat ini masih minim tersedianya suatu aplikasi mobile tentang anatomi tubuh manusia yang dapat meningkatkan minat membaca bagi masyarakat terutama pendidikan pada anak usia dini. Informasi yang terdapat pada buku - buku di perpustakaan yang tersedia pun tidak selalu dimanfaatkan karena kurangnya 
minat membaca melalui media buku pada perkembangan teknologi informasi dan komunikasi saat ini dan rentan rusak akibat debu dan lembab di dalam ruangan.

Rendahnya minat membaca buku dari kalangan siswa dan masyarakat umum dapat diminimalkan dengan memanfaatkan gadget sebagai media baca dan belajar tentang pengenalan anatomi tubuh manusia, ini dimaksudkan agar pemahaman tentang bagian tubuh manusia dapat lebih mudah dimengerti, dengan perkembangan teknologi sekarang ini membuat sarana atau media belajar beradaptasi menyesuaikan keadaan, dengan membuat aplikasi yang menarik sebagai pembelajaran untuk pengenalan anatomi tubuh manusia. Aplikasi tersebut ditanam pada gadget agar supaya dapat digunakan dengan mudah dan dapat dibawa kemana saja.

Berdasarkan uraian diatas, maka peneliti akan mengangkat judul "Aplikasi Pengenalan Anatomi Tubuh Manusia Berbasis Android". Aplikasi ini akan dibuat kedalam dua bagian, yaitu bagian pertama adalah pembelajaran yang berisi informasi seputar nama - nama sistem organ pada anatomi tubuh manusia. Dan kedua adalah kuis, dimana nantinya pengguna akan diuji pengetahuannya berdasarkan informasi yang telah diberikan sebelumnya.

Berdasarkan identifikasi masalah di atas maka dapat dirumuskan beberapa permasalahan, yaitu bagaimana pembuatan aplikasi pengenalan anatomi tubuh manusia, bagaimana membuat informasi yang ditampilkan menjadi lebih menarik, kemudahan - kemudahan yang bisa diperoleh dari aplikasi tersebut, dan bagaimana cara kerja fitur tersebut.

Adapun tujuan penelitian ini yaitu bagian pertama adalah membuat sebuah Aplikasi Pengenalan Anatomi Tubuh Manusia yang lebih menarik dengan menggunakan media smartphone, bagian kedua adalah membuat sebuah Aplikasi Pengenalan Anatomi Tubuh Manusia secara digital sehingga mudah di akses kapanpun dan dimanapun keberadaannya, bagian ketiga adalah memberi informasi pembelajaran yang efektif dan efisien secara offline, dan keempat adalah memberikan kemudahan dan dapat digunakan masyarakat umum dalam mengolah data dengan mudah dalam mengaksesnya.

Penelitian ini diharapkan dapat memberikan manfaat bagi semua pihak yang terkait, adapun manfaatnya dapat dilihat dari beberapa aspek yaitu manfaat dari segi teori adalah memberikan kontribusi seputar pengembangan metode dan materi yang diberikan dalam mengasah dan menambah pengetahuan dan wawasan tentang anatomi tubuh manusia yang ada pada tubuh kita, manfaat dari segi kebijakan adalah memberikan arahan kebijakan untuk pengembangan pendidikan bagi pada anak usia dini dalam pembelajaran anatomi tubuh manusia di bidang biologi yang baik dan efektif untuk diterapkan dan diajarkan, berkaitan dengan materi dan metode yang digunakan dalam pembelajaran di sekolah, manfaat dari segi praktik terdiri dari tiga bagian, yaitu bagian pertama adalah mendapatkan dekripsi, gambaran dan refrensi tentang perbandingan proses pembelajaran organ tubuh manusia dengan model torso manusia, bagian kedua adalah dapat dijadikan model pembelajaran sebagai referensi bagi peneliti sebagai pendidik, dan memberikan pengalaman nyata dari proses penelitian, menambah ilmu dan wawasan bagi peneliti mengenai proses pembelajaran anatomi tubuh manusia dan ketiga adalah menambah pengalaman bagi peneliti dalam mengolah suatu penelitian mulai dari awal sampai pada kesimpulan yang diperoleh dari penelitian, manfaat dari segi isu serta aksi sosial adalah memberikan informasi kepada semua pihak mengenai pembelajaran anatomi tubuh manusia pada anak usia dini sehingga dapat menjadi bahan masukan untuk lembaga - lembaga formal maupun non formal mengenalkan dan mempelajari pengetahuan tentang anatomi tubuh manusia.

\section{PENELITIAN RELEVAN}

Penelitian yang relevan dilakukan sebagai referensi dalam pembuatan penelitian yang peneliti buat, adapun contoh penelitian dari jenis penelitian yang sama sebagai bahan pembanding dengan penelitian yang saat ini dilakukan. Berikut adalah kedua daftar penelitian yang dilakukan oleh peneliti yaitu bagian pertama adalah nama judul yaitu "Aplikasi Media Pembelajaran dan Pengenalan Organ Tubuh Manusia Berbasis Multimedia", nama peneliti yaitu Prawido Utomo dkk, dan hasil penelitian adalah berupa aplikasi teknologi multimedia sebagai media pendukung dalam kegiatan belajar mengajar antara guru dan peserta didik lebih mudah mencerna pelajaran dengan baik dibandingkan dengan metode pembelajaran yang sebelumnya. Dan kedua adalah nama judul yaitu "MY BODY: Aplikasi Pembelajaran Organ Vital dan Tulang pada Rangka Tubuh Manusia menggunakan Augmented Reality", nama peneliti yaitu Lina Fitriyani dkk,dan hasil penelitian 
adalah sebagai media pembelajaran yang interaktif yang dibutuhkan untuk siswa dalam memberikan kemudahan dalam pembelajaran IPA khususnya bagian organ vital dan rangka tubuh manusia.

\section{METODE PENELITIAN}

Metode penelitian adalah salah satu teknik atau cara mencari data, memperoleh, mengumpulkan atau mencantumkan data yang tepat digunakan untuk keperluan dan faktor - faktor yang berhubungan dengan pokok pembahasan sehingga akan dapat suatu kebenaran atas data yang diperoleh. Peneliti menggunakan metode penelitian menggunakan prototype. Menurut Andikos \& Gusteri prototype merupakan suatu metode dalam pengembangan sistem yang menggunakan pendekatan untuk membuat sesuatu program dengan cepat dan bertahap sehingga segera dapat dievaluasi oleh pemakai. Prototype mewakili model produk yang akan dibangun atau mensimulasikan struktur, fungsionalitas dan operasi sistem (Andikos \& Gusteri, 2016). Dalam tahapan - tahapan dalam pembuatan prototyping terbagi kedalam tiga bagian, yaitu bagian pertama adalah mendengarkan pelanggan yaitu pada tahap ini dilakukan pengumpulan kebutuhan dari sistem dengan cara mendengar keluhan dari pelanggan. Untuk membuat suatu sistem yang sesuai kebutuhan, maka harus diketahui terlebih dahulu bagaimana sistem yang sedang berjalan untuk kemudian mengetahui masalah yang terjadi. Bagian kedua adalah merancang dan membuat prototype yaitu pada tahapan ini, dilakukan perancangan dan pembuatan prototype system. Prototype yang dibuat disesuaikan dengan kebutuhan sistem yang telah didefinisikan sebelumnya dari keluhan pelanggan atau pengguna. Dan ketiga adalah uji coba yaitu pada tahap ini prototype dari sistem di uji coba oleh pelanggan atau pengguna. Lalu dilakukan evaluasi kekurangan kekurangan dari kebutuhan pelanggan. Pengembangan kemudian kembali mendengarkan keluhan dari pelanggan untuk memperbaiki prototype yang ada.

Ada empat langkah yang menjadi karakteristik metode prototyping yaitu bagian pertama adalah pemilahan fungsi yaitu mengacu pada pemilahan fungsi yang harus ditampilkan oleh prototyping. Pemilahan harus selalu dilakukan berdasarkan pada tugas-tugas yang relevan yang sesuai dengan contoh kasus yang akan diperagakan.Bagian kedua adalah penyusunan sistem informasi yaitu bertujuan untuk memenuhi permintaan akan tersedianya prototype. Bagian ketiga adalah evaluasi Dan keempat adalah penggunaan selanjutnya.

Dalam pengumpulan data dan informasi mengenai obyek penelitian ini, agar pengerjaan lebih mudah dan memberikan sebuah informasi yang obyektif maka digunakan beberapa metode yaitu dengan metode studi pustaka (Library Research) yaitu merupakan tindakan yang dilakukan oleh penelitian untuk menghimpun informasi yang relevan dengan topik atau masalah yang akan diteliti untuk perancangan aplikasi anatomi tubuh manusia berbasis android. Peneliti memperoleh informasi dari buku - buku mengenai anatomi pada tubuh manusia, sumber referensi, dan mempelajari cara membuat android di internet dan video tutorial, peneliti melakukan studi pustaka ini berdasarkan referensi dari berbagai diskusi pembahasan baik dengan dosen maupun dengan orang yang berkompeten pada masalah kasus permasalahan ini.

Metode studi lapangan terdiri dari dua langkah, yaitu bagian pertama adalah survey yaitu digunakan untuk mendapatkan informasi dalam bentuk opini dari sejumlah orang atau masyarakat terhadap isu dan topik tertentu. Dan kedua adalah observasi yaitu merupakan teknik pengumpulan data dengan mengadakan pengamatan secara langsung terhadap suatu objek dalam periode tertentu dan melakukan pencatatan secara sistematis tentang hal - hal yang diamati. 


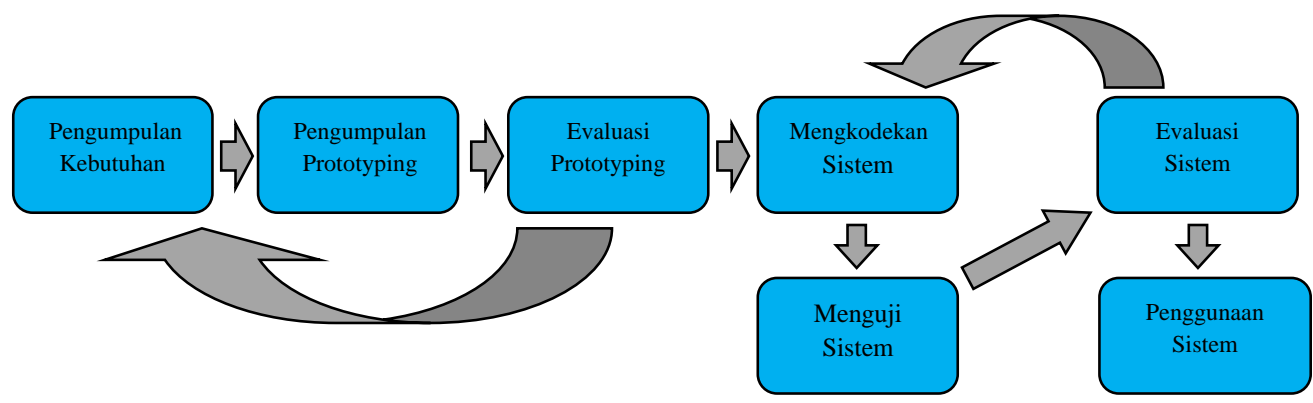

Gambar 1. Tahapan - Tahapan Prototyping

(Sumber : rizalloa.ilearning.me)

Dari gambar diatas untuk menyempurnakan hasil dari penelitian ini, peneliti mencoba menuliskan langkah - langkah yang di lakukan dalam pengembangan sistem berbasis android sebagai berikut, yaitu langkah pertama adalah pengumpulan kebutuhan yaitu pada tahap pengumpulan kebutuhan, pelanggan dan pengembang bersama - sama mendefinisikan format dan kebutuhan keseluruhan perangkat lunak, mengidentifikasikan semua kebutuhan, dan garis besar sistem yang akan dibuat. Langkah kedua adalah membangun prototyping yaitu pada tahap pembangunan prototyping, pelanggan dan pembuat sistem bersama - sama membuat format input maupun output yang akan dihasilkan oleh sistem yang dibuat. Langkah ketiga adalah evaluasi prototyping yaitu setelah tahap pembangunan prototyping. Pelanggan dan pengembang bersama - sama mendefinisikan format dan kebutuhan keseluruhan perangkat lunak, mengidentifikasikan semua kebutuhan, dan garis besar sistem yang akan dibuat. Jika sudah sesuai maka langkah keempat akan diambil, jika tidak prototyping direvisi dengan mengulang langkah pertama, kedua, dan ketiga. Langkah keempat adalah mengkodekan sistem yaitu dalam tahap ini prototyping yang sudah disepakati diterjemahkan kedalam bahasa pemograman yang sesuai. Langkah kelima adalah menguji sistem yaitu pada tahap pengujian sistem, koding yang telah dibuat sebelumnya akan diuji apakah dapat berjalan dengan baik ataukah masih ada bagian - bagian yang perlu diperbaiki atau apakah masih ada bagian yang belum sesuai dengan keinginan pelanggan. Pengujian ini dilakukan dengan White Box, Black Box, Basic Path, pengujian arsitektur, dan lain - lain. Langkah keenam adalah evaluasi sistem yaitu bukanlah evaluasi prototyping, evaluasi sistem adalah mengevaluasi sistem atau perangkat lunak yang sudah jadi apakah sudah sesuai dengan keinginan pelanggan atau belum. Jika belum, maka sistem akan direvisi kembali dan kembali ke langkah keempat dan kelima. Jika sistem sudah dikatakan OK maka sistem siap dilanjutkan pada tahap selanjutnya. Dan langkah ketujuh adalah menggunakan sistem yaitu tahap ini merupakan tahap akhir dari pembuatan sistem dengan metode model prototyping. Pada tahap ini perangkat lunak yang sudah jadi dan sudah lulus uji, siap untuk digunakan oleh pelanggan/user.

\section{HASIL DAN PEMBAHASAN}

Hasil dan pembahasan dari pembuatan aplikasi pengenalan anatomi tubuh manusia adalah sebagai berikut:

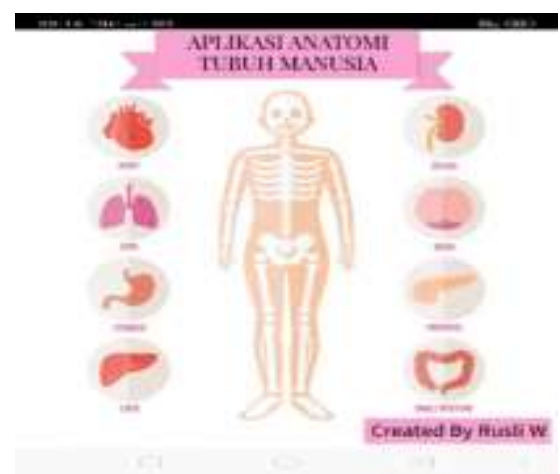

Gambar 2. Tampilan Splash Screen 
Tampilan awal yang pertama kali muncul saat aplikasi sebelum masuk kehalaman Menu Utama Splash Screen digunakan untuk menampilkan logo dan mempunyai kisaran waktu 3 sampai dengan 5 detik kemudian setelah waktu yang ditentukan selesai maka akan masuk Menu Utama.

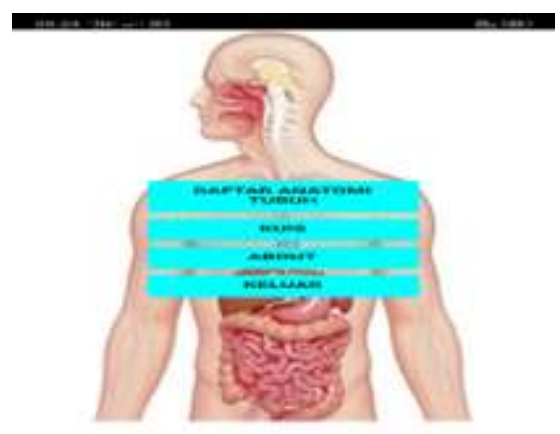

Gambar 3. Tampilan Menu Utama

Ditunjukan agar pengguna dapat memilih jenis menu yang akan dibuka. Di dalam tampilan menu ini memiliki empat tombol, yaitu tombol pertama adalah tombol Daftar Anatomi Tubuh jika di klik maka akan masuk ke tampilan tombol daftar nama sistem pada anatomi tubuh manusia yang terdiri dari Sistem Pencernaan, Sistem Pernapasan, Sistem Peredaran Darah, Sistem Saraf, Sistem Urinaria, Dan Sistem Indra. Tombol kedua adalah tombol Kuis jika di klik maka akan masuk ke tampilan kuis. Tombol ketiga adalah tombol About jika di klik akan menampilkan tampilan nama aplikasi dan profil pembuat aplikasi. Dan tombol keempat adalah tombol Keluar jika di klik maka akan keluar dari aplikasi.

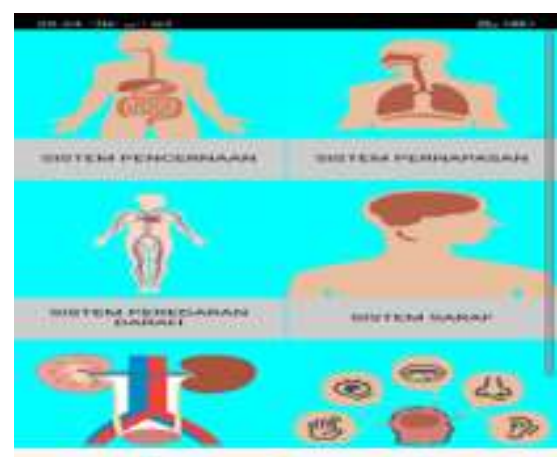

Gambar 4. Tampilan Daftar Anatomi Tubuh

Tampilan Menu Daftar Anatomi Tubuh terdapat tujuh tombol yaitu: tombol Sistem Pencernaan, tombol Sistem Pernapasan, tombol Sistem Peredaran Darah, tombol Sistem Saraf, tombol Sistem Urinaria, tombol Sistem Indra, dan tombol Kembali. Jika pengguna memilih salah satu dari tombol awalan kata Sistem tersebut, maka aplikasi akan dialihkan ke tampilan daftar nama organ. Dan jika pengguna memilih tombol Kembali, maka aplikasi akan dialihkan ke tampilan Menu Utama.

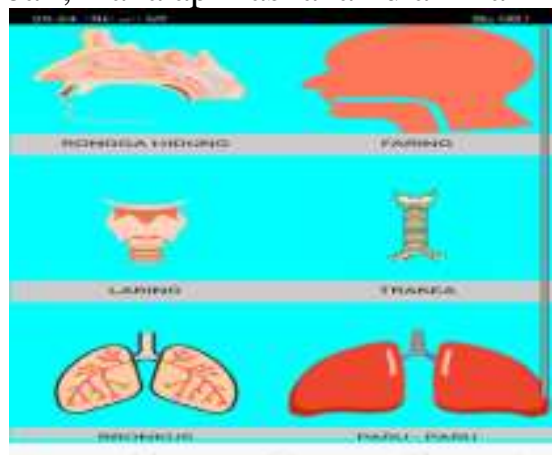

Gambar 5. Tampilan Daftar Nama Organ 
Pada tampilan ini akan menampilkan tombol list daftar nama organ berdasarkan tombol yang dipilih sebelumnya pada Menu Daftar Anatomi Tubuh dan tombol Kembali. Contoh pengguna memilih, maka pada tampilan ini akan menampilkan tombol list daftar nama organ yang telah dipilih. Dan jika di klik maka akan dialihkan ke tampilan informasi organ. Jika pengguna memilih tombol Kembali, maka aplikasi akan dialihkan ke tampilan Daftar Anatomi Tubuh.

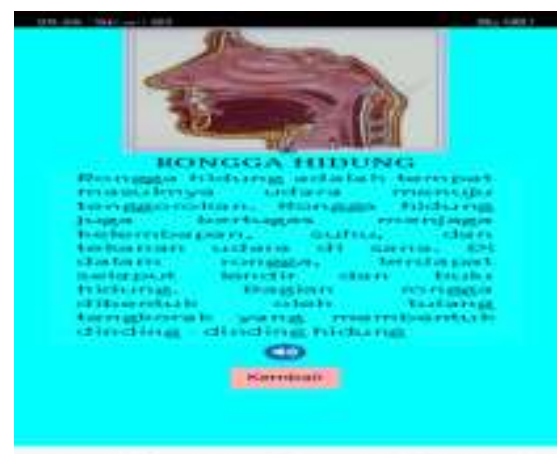

Gambar 6. Tampilan Informasi Organ

Pada tampilan ini akan menampilkan informasi organ berdasarkan tombol yang dipilih sebelumnya dan tombol Kembali. Contoh pengguna memilih, maka pada tampilan ini akan menampilkan informasi organ yang telah dipilih. Jika pengguna memilih tombol Kembali, maka aplikasi akan dialihkan ke tampilan Daftar Nama Organ.

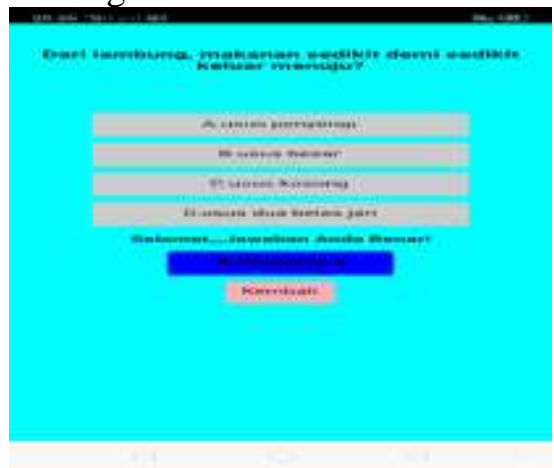

Gambar 7. Tampilan Kuis

Pada tampilan Kuis akan dipaparkan soal random secara berurutan lalu disediakan empat tombol pilihan jawaban, tanda pernyataan soal benar atau salah dari soal tersebut disertai dengan suara, tombol Selanjutnya, dan tombol Kembali. Pengguna akan menjawab dari soal tersebut dengan memilih salah satu dari empat tombol pilihan jawaban yang disediakan. Apabila jawabannya benar maka pengguna akan diberikan pernyataan hasil jawaban benar pada tampilan dan apabila jawabannya salah maka akan diberikan pernyataan hasil jawaban salah pada tampilan. Jika pengguna memilih tombol Selanjutnya, maka tampilan soal akan dialihkan soal baru secara random. Jika pengguna memilih tombol Kembali, maka aplikasi akan dialihkan ke tampilan Menu Utama.

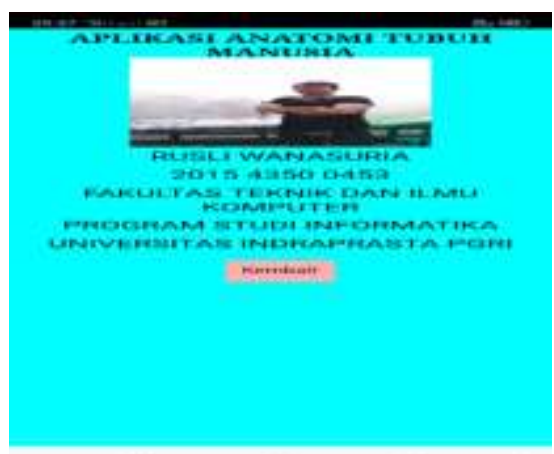

Gambar 8. Tampilan About 
Pada Menu About akan menampilkan informasi nama aplikasi dan informasi profil pembuat aplikasi pengenalan anatomi tubuh manusia serta tombol Kembali. Jika pengguna memilih tombol Kembali, maka aplikasi akan dialihkan ke tampilan Menu Utama.

\section{SIMPULAN}

Dari keseluruhan pembuatan Aplikasi Pengenalan Anatomi Tubuh Manusia Berbasis Android, dapat diperoleh kesimpulan sebagai berikut, yaitu pertama adalah jika aplikasi ini diimplementasikan pada SMA diharapkan dapat memudahkan dalam proses belajar khususnya materi anatomi tubuh manusia. Kedua adalah memberikan kemudahan bagi siapa saja untuk mempelajari materi anatomi tubuh manusia.Dan ketiga adalah aplikasi ini akan juga dapat dilihat oleh masyarakat yang ingin mengetahui materi tentang anatomi tubuh manusia.

\section{DAFTAR PUSTAKA}

Andikos, F., \& Gusteri, Y. (2016). Komunikasi Manusia Dengan Komputer. Bogor: In Media.

Fitriyani, L., Syahputri, R. E. N., \& Lovani, R. J. (2017). MY BODY : Aplikasi Pembelajaran Organ Vital dan Tulang pada Rangka Tubuh Manusia menggunakan Augmented Reality. Jurnal Teknik Informatika, 3(2), 1094. Retrieved from https://openlibrary.telkomuniversity.ac.id/pustaka/138917/my-body-aplikasi-pembelajaran-organ-vital-dantulang-pada-rangka-tubuh-manusia-menggunakan-augmented-reality.html

Utomo, P., Krisnadewi, S., \& Rahmad. (2016). Aplikasi Media Pembelajaran dan Pengenalan Organ Tubuh Manusia Berbasis Multimedia. Jurnal Sisfotek Global, 6(2), 91-96. Retrieved from http://journal.stmikglobal.ac.id/index.php/sisfotek/article/view/115 